\title{
Double Victims and Agents of Change in Europe's Margins: Estonian Emigrants Sharing 'Their' Repressive Soviet Past in the Netherlands
}

\author{
Inge Melchior
}

Many [Western Europeans] do not know about the Soviet period and the deportations and about those politics. Many do not even know that Estonia exists. [...] If I am honest, I think they are not interested in what has happened here.

LINDA

Linda, born in 1942 in the Estonian Soviet Socialist Republic, recalls, while telling me her story, how Soviet soldiers entered their house in 1949 to deport her sick father to Siberia. For her, the idea that Western Europeans do not share in this memory of Soviet repression, or might not even care, is very painful. She wants to belong to Europe. Since Estonia regained its independence in 1991, the new nation-state has successfully framed its identity as 'European', as always having belonged to Europe, as an antipode to Soviet. ${ }^{1}$ Not only Estonians from the generations who actually experienced Soviet repression, but also the younger generations born in the 1970 and 1980 s, who grew up during the struggle for independence, have voiced their concerns to me about 'Western Europe not being able to comprehend' the Estonian historical experience (Sirje, 1982).

Based on previous extensive ethnographic fieldwork, I have argued that Estonians from various social groups perceive their national memory narrative to be inferior to the dominant Western European one. ${ }^{2}$ This leads to feelings of

1 Eiki Berg, "Local resistance, national identity and global swings in Post-Soviet Estonia," Europe-Asia Studies 54-1 (2002): 109-122.

2 Inge Melchior, "Guardians of Living History: The Persistence of the Past in post-Soviet Estonia" (Phd diss., vu University Amsterdam, 2015). Inge Melchior, "Forming a common European memory of wwII from a peripheral perspective: Anthropological insight into the struggle for recognition of Estonians, wwII memories in Europe," in Disputed memory: 
insecurity, of not belonging to the 'European family' and not being taken seriously as equal partners. For this chapter I have followed Estonians who moved to the Netherlands, in order to get a deeper understanding of what actually happens when the 'Estonian memory narrative' is transported into Western Europe. What do Estonian grassroots' memory agents do when they experience different reactions to/receptions of their understanding of the past? In what kind of contexts does this exchange of stories happen?

This chapter will reveal that in addition to the 'double victims' that I have described extensively in my previous work, Estonians who moved to the Netherlands present themselves sometimes as 'agents of change'. Both double victims and agents of change cannot just do 'nothing'; both feel the need to create understanding and recognition among the Dutch, to pay respect to the stories of their relatives. For many this also means they feel the need to 'defend' or at least explain their national politics, which are much entangled with their family stories. Agents of change, however, believe that they have a voice that counts in that foreign context. They believe that they can make a change, that they can teach a life lesson that their Dutch friends are unable to learn from their own 'rather uncomplicated' history.

Based on the above, this chapter will provide a deeper understanding of memory reception. I will first explore the theoretical background of memory making and reception in the context of migration. Then I will explain how and among whom I have gathered my data. In the empirical part I will show what happens when migrants share their memory narratives in a host country within a rather dominant discourse.

\section{Theory on Memory Reception}

Representations of the past are being produced in museums, textbooks, monuments by cultural, intellectual and political elites, as well as during family dinners. However, as Wulf Kansteiner has elaborately pointed out, this does not necessarily mean that these representations turn into memory; meaning that the authors/tellers successfully tie the representations to specific social groups. ${ }^{3}$ Thus, instead of 'presuppose[ing] a rarely acknowledged but not particularly surprising desire for cultural homogeneity, consistency and predictability' in

emotions and memory politics in Central, Eastern and South-Eastern Europe, eds. Tea Sindbæk Andersen et al. (Berlin: de Gruyter, 2016) pp. 203-226.

3 Wulf Kansteiner, "Finding meaning in memory: a methodological critique of collective memory studies," History and Theory 41.2 (2002): 192, 179-197. 
memory studies, we should have a closer look at what happens on the reception side of memory. ${ }^{4}$ As an anthropologist I am not interested in the direct reception of a collective representation of the past. Rather, I am interested in how individuals, who have incorporated a certain memory of the past, interact with individuals who adhere to different representations of the past. How do the traces of the past that last within people, act upon them and make them act in a context among 'others'?

The answer to this question depends on the context. Memories of suffering are different from other kind of traces from the past. Several memory scholars have written about such 'traumatic memory': the kind of memory that does not find meaning in a narrative and thus retains its strong and uncontrollable affective force. In those cases, speaking about the past is of immense importance for a sense of liberation from that past. Firstly, it will remind the world of its responsibility to acknowledge truths that have been denied. Secondly, it will heal the self by the very act of speaking and being heard, as it allows the birth of a narrative that provides meaning to the pain. ${ }^{6}$

The listener also plays a crucial role in the extent to which the past persists into the present. If there is no listener, the terrible event does not exist in the historic record. ${ }^{7}$ Perhaps even more painful is the 'unwitnessed event', described by psychoanalysts as the 'annihilating force when others are around and do not acknowledge the inhumanity in front of them.. ${ }^{8}$ Or as anthropologist Michael Lambek puts it: ' $[t]$ here is nothing worse than making the effort to speak of terrible things and being ignored.9 ${ }^{9}$ The empathy of the listener is not only crucial at the moment of storytelling, but also in what he/she does with the story afterwards.

Several memory scholars have argued that not only those who lived through a traumatic event have a memory that can extend into the present, but that also the post-generation can embrace the memory as their own, as

4 Kansteiner, "Finding meaning in memory," 193.

5 David Berliner, "The abuses of memory: reflections on the memory boom in anthropology," Anthropological Quarterly 78.1 (2005).

Jeffrey K. Olick \& Joyce Robbins, "Social memory studies: From 'collective memory' to the historical sociology of mnemonic practices," Annual Reviews of Sociology 24 (1998).

6 Katharine Hodgkin \& Susannah Radstone. "Remembering suffering: trauma and history," in Contested pasts: the politics of memory, ed. Katharine Hodgkin et al. (London: Routledge, 2003).

7 Nancy R. Goodman, and Marilyn B. Meyers, ed., The power of witnessing: Reflections, reverberations, and traces of the Holocaust (London/New York: Routledge, 2012), 3.

8 Goodman, The power of witnessing, 10.

9 Michael Lambek, "Foreword," in Memory and World War II: An Ethnographic Approach, ed. Francesca Cappelletto. (Oxford: University of Chicago Press, 2005), xi. 
a 'post-memory'. ${ }^{10}$ The descendants of victims - such as young generations Estonians - feel so deeply connected to the traumatic experiences of their (grand)parents, 'that they need to call that connection memory and thus that, in certain extreme circumstances, memory can be transmitted to those who were not actually there to live an event'.11 The second generation has made the stories with which they grew up their 'own' to such a large extent that the experience of the trauma extends into the present.

The desire to 'compensate' the others' losses ${ }^{12}$ is especially strong in times of uncertainty, when the wounds of the past hurt the post-generation more, and coherent stories of the past are more essential to the healing process. ${ }^{13}$ 'When identity is not in question, neither is memory.' ${ }^{14}$ In other words, in times of crisis or uncertainty the post-generation will be more likely to demand recognition for their story. The peculiarity of the Estonian post-generation on which I will focus in this chapter, is that they live in a foreign society.

Generally, migrants face more uncertainty than natives do. According to anthropologist Liisa Malkki, this is due to the fact that migrants are seen, and see themselves, as 'uprooted'. Like most people, migrants long for roots, in order to feel at home in a place and to have intimate ties with other people. Migrants face more challenges than natives in rooting themselves as they move between physical spaces and between cultural communities. They live as if they were 'in-between' cultures. They have their roots in a different society than the place where they are living. They constantly need to 'decide' to which social and cultural rules they will adhere, with whom they identify and to whom they are loyal. This makes them unpredictable and therefore they are sometimes seen as 'scary' by their host society. A strong story or narrative provides guidance in this chaos and cultural 'in-betweenness'.15 Eastmond argues that stories and narratives help people in times of migration to establish identity in their ruptured life paths. ${ }^{16}$

\footnotetext{
$10 \quad$ Marianne Hirsch, "The generation of postmemory," Poetics Today 29.1 (2008).

11 Hirsch, "Postmemory," 105-106.

12 Kansteiner, "Finding meaning in memory," 184.

Olick, "Social memory studies."

13 Hodgkin, "Remembering suffering."

14 Michael Lambek and Paul Antze, "Introduction: Forecasting memory," in Tense past: Cultural essays in trauma and memory, ed. Michael Lambek et al. (New York: Routledge, 1996), xxii.

15 Liisa H. Malkki, Purity and exile: violence, memory, and national cosmology among hutu refugees in Tanzania (Chicago: The University of Chicago Press, 1995).

16 Marita Eastmond, "Stories as Lived Experience: Narratives in Forced Migration Research," Journal of Refugee Studies 20.2 (2007).
} 
Based on the preceding paragraphs we might expect that those Estonians who live in the Netherlands and feel that their Estonian identity is under threat, are more likely to defend and demand recognition for the story of Soviet repression. In the new context where they live, that story is being challenged, and therefore can become an identity marker of Estonian national identity. For those who do not strongly identify with the victims of Soviet repression or with the Estonian nation, or who do not feel that their Estonian identity is under threat in their new homeland, we might expect the opposite: that the physical distance to the homeland creates more emotional distance to its identity markers.

I have thus singled out several contextual factors that feed into the lingering effect of the past into the present, and thus the need that people feel to share their story with others: a violent and traumatic past, the absence of an empathetic listener, a high degree of identification with the victims, as well as a strong sense of insecurity and chaos in the present. A contextual factor, which is especially important to add to this list in the case of migrants, is the power of the particular migrant(group). First of all, migrants who enter a new society through a refugee camp have completely different possibilities to turn their experiences into narratives and share them with their new compatriots, than those who integrate into an urban area. ${ }^{17}$ But even though most Estonian migrants in this chapter live in Dutch urban areas and are well educated, they face the fact that the 'established' have more power because they have better access to institutions, more knowledge about the society in which they live and a stronger social network. ${ }^{18}$ As the 'outsiders', migrants have less legitimacy to their own story in their new homeland - especially if the narrative challenges the dominant story.

In this text I will focus on the reception in the Netherlands of the Estonian grand narrative on the Soviet repressions, which challenges the Dutch narrative on the Holocaust. It concerns a violent past that lingers on in the present for many of my interviewees, in their search for an empathetic listener.

\section{Methodology}

Wulf Kansteiner argues that reception is too little studied in the field of memory studies. ${ }^{19}$ Too often do memory scholars assume that the dominant story

17 Malkki, Purity and exile.

18 Norbert Elias and John L. Scotson, The established and the outsiders (New York: The Humanities Press, 1966).

19 Margaret Archer in Kansteiner, "Finding meaning in memory," 194. 
in the media correlates with the perspective of its users, also called the 'downward conflation' of structuralism. ${ }^{19}$ Therefore, I have chosen an ethnographic fieldwork approach in order to be able to focus on the social practices of remembering and to avoid sticking solely to the level of representation and memory producers. Ethnography also enables a focus on the agency that people have and on emotions that can be found below the surface.

Since 2007, when I conducted research for my Master thesis in Estonia, I have participated in activities of the Eesti Kool [Estonian school] in the Netherlands, after returning from fieldwork. Once a month they organize 'classes' for the children of Estonian parents in order to improve their Estonian language and to nourish their Estonian identity, and they provide language lessons for adults. 1100 Estonian citizens are officially registered in the Netherlands. I participated in the language classes until they no longer contributed to my language skills. I continued to attend events such as the St John's celebration every year in June. For this text I have carried out participant observations during monthly school days and interviewed several Estonian emigrants. These Estonians have moved to the Netherlands to study, work or because they have a Dutch partner. They are thus institutional or labor migrants who emigrated voluntarily. I approached them by posting a message in the Facebook group 'Eestlased Hollandis' (Estonians in the Netherlands). The network has 1962 members (on 8 March 2016). I also invited several Estonians directly; either acquaintances from my time in Estonia who had emigrated, or people I had met during my previous participation in activities of the Estonian School. Eventually I managed to gather stories from seven Estonians, all conducted in the Estonian language, either written or by Skype interview.

This data collection should be seen as building on my previous ethnographic fieldwork research in Estonia between 2007 and 2015, where I participated in commemorations, song festivals and folk dance classes, in family dinners, berry picking excursions and relatives' graveyard visits, while conducting an extensive amount of formal and informal interviews.

I did not further select those Estonian emigrants who were willing to talk to me. After all, what I am interested in is the fact that they as Estonians live within the Dutch memory landscape, and how they deal with that. Based on my previous fieldwork I would not expect major differences between individuals, as I saw how the stories of Soviet repression mattered to my informants from all parts of society, as they all identify with the Estonian nation and feel responsible for its preservation and continuation, especially, I would expect, in a foreign context, where they live among people who adhere to different stories about the recent past. They are confronted with them on a daily basis. Reception and incorporation of the Soviet narrative might therefore be different for them than for Estonians who live in Estonia. After all, they are also 
exposed to another memory narrative of that same time period, namely the one which is dominant in the Netherlands. 2014-2016 forms a very interesting time to collect data in the Netherlands, as - I will argue - the image of Russia has recently changed, due to current political developments.

\section{The Memory Narrative of Soviet Repression}

On the 25th of March 1949 we were taken away from our house. [...] We had seen how they set everything on fire, and how they filled their pockets with the things that were useful to them. From the trip I remember mainly how those Russians were screaming at us: 'fascists'. And the cold. There was so much snow outside and people were sleeping in front of the door. We had 5 families in our cattle wagon. [...] We were in the train for about a month before we arrived.

ELIISA, 1940

Eliisa was deported to Siberia as a 9-year old girl, together with her mother. Apart from her, another 33,861 Estonians ( $=3 \%$ of the total population of 1939) have lived parts of their lives in Gulag (Soviet forced labour camps) accused of being 'enemies of the people'. ${ }^{20}$ This number excludes political prisoners sent to Russia, men mobilized into the Red Army and people arrested and murdered on the spot. In total, 134,6oo Estonians - men, women, elderly people, children, intellectuals, farmers and workers - were repressed by the Soviet regime between 1939 and 1991 in one or another way. Not only Estonian families have been deprived of their freedom by the Soviet authorities. People of all ethnicities living in Soviet territory - Russians, Ukrainians, Latvians, Georgians, Uzbeks, Jews, Chechens, etc. - were in potential danger if they did not live according to the Communist rules. ${ }^{21}$ Historians have estimated that between 1928 and 1953, about 25 million people in total had circulated through the Gulag system. ${ }^{22}$

$20 \quad$ Aigi Rahi-Tamm, "Human losses," in The white book: losses inflicted on the Estonian nation by occupation regimes 1940-1991, ed. Vello Salo et al. (Tallinn: Estonian Encyclopaedia Publishers, 2005).

21 Richard M.C. Mole, The Baltic States from the Soviet Union to the European Union: Identity, discourse and power in the post-communist transition of Estonia, Latvia and Lithuania (London: Routledge, 2012).

22 Jehanne M. Gheith and Katherine R. Jolluck, Gulag voices: Oral histories of Soviet incarceration and exile (New York: Palgrave Macmillan, 2011), 3. 
Eastern Europeans grew up in the 'bloodlands', the land between Moscow and the German border, the place where Hitler and Stalin fought each other's armies and where terror would inevitably intrude in the everyday lives of the locals at some point. ${ }^{23}$ Estonia became a kind of plaything of history, being a small country $(1,133,917$ inhabitants in 1939, source: stat.ee) with a short independent history (1920-1939) and a strategic geo-political location. In 1939, the country was annexed by the Soviet Union. In 1941 the German troops arrived and took over control. Estonian men were mobilized both into the Soviet and German army. In 1944, when the Soviet army again approached the Baltic States, ten thousands of Estonians joined the German army voluntarily in order to defend their home country. On the battlefields they faced their own brothers, fathers, friends and neighbours, men who had been recruited into the Soviet army. Eventually the Soviet authorities expelled the German rulers and stayed in control until 1991.

In those almost 50 years of the Estonian Soviet Socialist Republic (ESSR), a public memory of the deportations, as the ultimate symbol of Soviet repression, did not exist. Eliisa returned with her mother in 1958, and told me how she was not 'allowed' to talk about the deportations. First of all, former deportees had problems entering certain jobs and universities. Secondly, the public narrative framed the deportees as criminals and enemies of the state, who had been transferred to Siberia in order to safeguard the rest of society. People like Eliisa thus felt ashamed mentioning the fact that they had been one of the deportees.

Only in the late 1980s, in the period of glasnost and perestroika, did a public memory narrative of Soviet repression find daylight. In the ESSR this started with the publication of 'Maria in Siberian lands' [Maria Siberimaal]. Heino Kiik wrote this novel about his deported mother and brother and arrested father already in 1978, but it only made it to the wider public after 1985 (Eesti Päevaleht, 15 May 2009). With that, the Soviet deportations had come to occupy a place in the cultural memory of the ESSR as a narrative about the repression of innocent people rather than the punishment of criminals. The publication of this book and the first newspaper articles on this topic (for example, on 27 November 1987, historian Evald Laasi wrote an article about the Soviet deportations in the main Estonian cultural magazine Sirp ja Vasar ('Hammer and sickle')), broke a taboo in Soviet Estonian society. Similar events were taking place in Soviet Russia and other Soviet republics. ${ }^{24}$

\footnotetext{
23 Timothy Snyder, Bloodlands: Europe Between Hitler and Stalin (Philadelphia: Basic Books, 2010), vii-viii.

24 Nanci Adler, "The Gulag Survivor: Beyond the Soviet System," in On Living Through Soviet Russia, edited by Daniel Bertaux, et al. (London: Routledge, 2004).
} 
Alongside the creation of this cultural memory, politicians also began to openly create a safe space for sharing stories of Soviet repression, even though Estonia was still part of the Soviet Union and politicians were still subject to Soviet authority (more on this in Melchior, 2015, pp. 91-100 and 116-136). On 25 March 1989, exactly 40 years after the second mass deportation, head of state Arnold Rüütel held a public speech and on 14 June, the date of the 1941-deportations, three government officials made an 'Address to the people of Estonia'; both acts 'politically' recognized the victimhood of the deportees. ${ }^{25}$

This new public memory touched the former deportees deeply. Leena, who had been deported in 1949 at the age of 6, recalls in our interview what had happened to her when she first got hold of a copy of 'Maria in Siberian lands': 'I just read and cried. It tore open all the old wounds. I did not want to experience it anew [...]. When I read the book at home, my children told me not to read the book, because I just cried the whole time. But I had to read and cry anyway. When I recall that time and read some old letters from that time, my heart starts to hurt' (Leena 1949). Once the story of Soviet repression was out in the open, things developed quickly. On the radio a series was launched called 'Unwritten Memoirs' [Kirjutamata memuaare], where deportees told their stories publicly.

In addition, young and critical intellectuals founded the Heritage Society in 1987 and started to collect life-stories. In the wake of Jakob Hurt, a great Estonian folklorist and linguist from the period of National Awakening, these young intellectuals believed that real history existed in the stories of the people, untouched by politics. ${ }^{26}$ National history in Estonia was thus rewritten by intellectuals, dissidents and ordinary citizens collectively, from a non-academic and personal perspective. A broad share of the population was involved, as basically every Estonian knew someone who had been deported and/or was confronted with the wounds of the past. In the wake of the wider 'Singing Revolution' - in which those intellectuals, dissidents and the majority of Estonian-speaking citizens peacefully participated in song festivals to express their cultural strength and demand freedom - Estonian deportees were explicitly called for filling in the gaps in the official history. Former deportees received special status and became 'irreplaceable' compatriots for having the

25 Terje Anepaio, "Reception of the topic repressions in the Estonian society," Pro Ethnologia $14.9(2002): 5^{0 .}$

26 In my doctoral dissertation I dedicated a full chapter to the tracing of the mobilization of history-writing of the Estonian nation. 
knowledge that others did not have. ${ }^{27}$ It could be argued that production and reception of memory in those early 1990s were inextricable linked. 'The people' produced and 'the people' received, at least that was how my informants perceived the situation at that time. ${ }^{28}$

Obviously, this relationship changed when time passed by. The intellectuals and dissidents who had been the unofficial and ordinary leaders of the 'Estonian people' in the late 1980s, became the politicians of the new Estonian state re-established in 1991. In the late 1990s, their focus was no longer with the past but with the future, according to Anepaio. ${ }^{29}$ Society by that time had split into two: the independence winners and the losers. The losers increasingly felt that they were not being represented by the political elite. They began to share stories of the good and secure Soviet life in their personal sphere. In the 2000s, these stories of innocent Soviet nostalgia also entered the public stage, but only in the cultural (writers and film / theatre directors) and intellectual (academia) arena and the topic was very cautiously addressed. ${ }^{30}$ Attempts by intellectuals or cultural figures to talk about the 'normal' Soviet life, were easily quelled by calling them 'Communist' or 'national traitor'. On a political and legal level the memory narrative of Soviet repression never lost ground. Estonian ethnologist Kirsti Jõesalu argues that all presidents between 1991 and 2012 frame the Soviet period as a rupture, an abnormal and non-Estonian time. ${ }^{31}$ Moreover, the ideology of 'legal restorationism' implemented in Estonia in the early 1990 s frames the Soviet period in legal terms as illegal. ${ }^{32}$

Since 2004 Estonia is a member of the European Union (EU). This has posed new challenges to the memory narrative of Soviet repression. After all, 'old Europe' does not have the same historical experiences with Communism and

27 Anepaio, "Reception."

Ene Kõresaar, "Memory and history in Estonian post-Soviet life stories" (PhD diss., Tartu University, 2004).

28 See Melchior, Guardians of living history.

29 Anepaio, "Reception."

30 Kristi Grünberg, (2009). "Remembering the Soviet past in Estonia: the case of the nostalgic comedy 'the light blue wagon'," Atslegvardi / Keywords: Academic Journal for New Research in humanities and Social Sciences in the Baltic States (2009), accessed 23 August 2010 available at http://www.satori.lv/projekti/keywords/Kristi_Grunberg.pdf.

Melchior, Guardians of Living History.

31 Kirsti Jõesalu, "The role of the Soviet past in post-Soviet memory politics through examples of speeches from Estonian presidents," Europe-Asia Studies 64.6 (2012): 1007-1032.

32 Vello A. Pettai, "Framing the past as future: the power of legal restorationism in Estonia" (PhD diss., Columbia University, 2004). 
the Soviet Union as 'new Europe' has. Besides that, a common European history based on the Holocaust as a unique crime against humanity was already in the making when Estonia entered. This has incited debates in Estonian society on how to deal with their memory of Soviet repression. Can they allow a Holocaust narrative into their historical consciousness without betraying their memory of Soviet repression? And if they are expected to incorporate the Holocaust narrative dominant in the west, does that mean Estonians can expect Western Europeans to do the same with the memory of Soviet repression? Helena, one of my informants, a history teacher born in 1975, explained to me her fear: 'I am curious whether that means that France is going to learn about Estonian history as well then. Did you learn anything in school about Estonian history? [...] It is just not fair. Why do we need to learn about France and England and the Netherlands, and no one is learning about us?' (Helena 1975). Helena is afraid that within the European family, the memory narrative of Soviet repression is not strong enough to persist. At the same time, she and the majority of Estonians do not want to turn their backs to Europe either, as they very much want to belong to Europe. ${ }^{33}$ Polish sociologist Piotr Sztompka traces this 'emergence of the crippled, inferior, deficient and defensive identity of "incomplete Europeans"' to the period of modern capitalism and the Cold War, both periods in which the region lost its temporary importance in Europe. $^{34}$

This is the memory narrative of Soviet repression in which the interviewees in this chapter were raised and the story they carried with them to the Netherlands. But how do they relate to that narrative in the Netherlands? Which meaning does it have in their everyday lives in this 'foreign' context? What do they do with the story?

\section{The Story of Soviet Repression in the Netherlands}

As mentioned before, the story of Soviet repression is not 'rooted' in the Netherlands. The Netherlands was never part of the Soviet Union, nor were their citizens directly affected by the Soviet authorities due to the lack of a relevant historical or political affiliation. Soviet repression is thus not part of the collective memory of the Dutch community, which also implies that few

33 Melchior, Guardians of Living History. Melchior, Forming a common European memory.

34 Piotr Sztompka, From East Europeans to Europeans: Shifting Identities and Boundaries in the New Europe (Wassenaar: NIAs/Netherlands Institute for Advanced Study in the Humanities and Social Sciences, 2004). 
Dutchmen have knowledge of what happened behind that iron curtain. It was a far from their bed show. My informants mention that when the Soviet past comes up in a conversation, it is mostly when contemporary politics evoke a debate. The topics that most easily evoke discussion when Dutch interact with Estonians are the role of Russia and the minority rights/refugee crisis.

Siim, born in 1997, moved to Maastricht for his first years of study. He got befriended with two Estonians, one Dutch and one Slovak guy. 'Russia' and 'Putin' regularly entered their conversations: 'I would say that our thoughts and feelings were not completely different, but in the beginning I definitely noticed some differences. For example when I think of Putin's or Russia's politics I am quite negative. But they were not very excited about the theme, they were relatively neutral towards Russia and Putin' (Siim, 1997). Anna, born in 1991, studied in Utrecht for some time, and had the most serious discussion when she invited a friend from the Netherlands over to Estonia during the summer. Even though he was a history teacher and Anna expected him to understand that Estonian history is different from the Dutch one, he was posing her very critical questions about the minority question in Estonia. It gave her the feeling that he did not understand her (and the general Estonian) perspective on the matter, and that he assumed that his perspective was somehow superior.

For both Siim and Anna, the story of Soviet repression did not lose its importance because they were living far away from their homeland. It rather increased because it was constantly being challenged and they felt the need to defend their standpoint. Moreover, for Estonians, the Soviet repressions are not solely a story of their nation, as we just saw, but a family story as well, with a strong sense of loyalty towards relatives. Important to stress here is that both Siim and Anna were born in independent Estonia, are highly educated and outward-looking individuals, and yet that painful national history affects the present. Siim explained as follows why the Soviet narrative is important to him, regardless of the place he lives:

WWII and the Soviet period are very much entangled with my family and therefore this topic is of great interest to me personally. The family of my grandfather on father's side was not deported, but their suitcases were packed and they were ready to go, but fortunately no one came to knock on their door. [...] The whole family of my grandmother on father's side was deported to Siberia in March 1949, somewhere close to Omsk and Kazakhstan. My grandmother Eda turned 9 years old in that animal's wagon on the way to Siberia. [...] My great-grandfather on mother's side, Karl Vares, disappeared without a trace. One thinks that 
he died somewhere in Siberia. He had been on the side of the Germans. [...] My grandmother on mother's side was an Ingrian. Also her family has suffered a lot because of wwII. [...] the family fled the war to Russia, from where they were deported to Siberia and eventually they returned to Viljandi (Estonia).

SIIM, 1997

Seeing his family history and his interest in that family history, it is understandable why the story of Soviet repression is close to his heart and has not lost its significance in the Netherlands. Also Liisa, born in 1977, who married a Dutch man in 2000 , immediately recalls her family stories while explaining to me why the story of Soviet repression lingers in her life:

You know it is a wound (haav) and it is still fresh. We have only been free for 20 years. It still hurts. My grandfather, my own grandfather, he was on the list to be deported. He was an entrepreneur, he owned apple trees. They came to get him twice. One time he was in the swamp, the second time he was literally on top of a tree in the garden, hiding, while his wife and children were in the house. He was in danger but luckily he was never deported. You know, one evening they could come to pick you up to fight in the Soviet army and the next one - or sometimes even the same evening - for the German army. There was not a matter of choice.

LIISA, 1977

Because of its close ties with one's family, the story of Soviet repression does not lose significance in the Dutch context. Kadri (1984) moved to the Netherlands in 2009, two years after she got into a relationship with a Dutch man whom she had met in Estonia. For Kadri the Soviet repressions are not only important because of her family story but because she as a citizen is directly related to that history. 'It plays a big role in the identity of Estonians. The Soviet occupation and the Singing Revolution are at least to my generation an important part of our identity' (Kadri, 1984). Only one of the interviewees, Marii, 32 years old, mentioned that the Soviet repressions did not interest her that much. Marii, who moved to Eindhoven to pursue her $\mathrm{PhD}$ research, never asked her family for their story, and apparently her relatives did not feel the need to share it with her either. For Marii, the story does not play any role in defining who she is, as a person or as an Estonian. Except for her, all interviewees mention that the story of Soviet repression not just passively lingers on in the Dutch context, but rather seems 'activated' as it is constantly being challenged. 


\section{An Equal Listener?}

Once the Estonian emigrants share the story of Soviet repression with their Dutch classmates, neighbours and colleagues, their Dutch interlocutors either react (1) indifferently or judgmentally, or (2) with surprise and interest. As argued before, it is very important for the healing process and for establishing a fruitful relationship with others that one feels understood. ${ }^{35}$

Siim explained to me that he often felt misunderstood by his Dutch friends 'who had much more liberal worldviews' when he spoke about the danger of Russia. During these conversations he got the impression that the Dutch are not very interested in the Baltic region, or make any effort to learn more about it:

They could not place themselves in my perspective, and in general Estonia, as an Eastern European state and as neighbour of Russia, was not a topic that touched them in any way. [...] Here, I want to strongly stress that Dutch people in the beginning thought that the Baltic States, including Estonia, are 'basically Russia'. Of course I did not like this at all and I tried to explain to them, again and again, that Estonia and the other Baltic States are independent and significantly different from Russia. I would bring examples about our culture, our language, that we have the Latin alphabet, not Cyrillic and that our languages are completely different. And that we are different as a Volk. We are Finn Ugric people, not Slavic, and so forth.

SIIM, 1997

Kadri shares the same feeling that the Dutch are indifferent towards what happened in that eastern region; they do not really care:

I think that the majority of Dutch people is not interested in Estonian history and does not understand it very well. Generally they still think about Eastern Europe as one single eastern bloc and they know that those countries were once part of the Soviet Union. More nuances generally do not fit to that world view. Europe ends with the eastern border of Germany and anything that comes after that does not evoke any interest. Of course there are also people who are interested in Estonian history, but those are the people who learned about it at university.

KADRI, 1984 
Anna's Dutch friend who came to visit her in Estonia - a history teacher - was not indifferent towards Estonian history; he was rather interested and asked many questions. But like those Dutch interlocutors mentioned before, he did not give Anna the feeling that he was making an effort to understand her or 'the Estonian' perspective. He was rather judgmental in his response to her stories:

When I elaborately tried to explain Estonian history to him, I got the feeling that he did not understand it very well. Especially when we spoke about the relationship of Estonians with Russia and the Russians living here. He suggested many things and drew parallels with what was happening in the Netherlands. That people who come to the Netherlands are immediately forced to study the language, so that they will quickly integrate into their new society. It was difficult to convince him that it is not so easy to accomplish that in Estonia.

ANNA, 1991

In order to avoid the pain of being misunderstood, Saara (1970) rarely speaks with Dutch people about the Soviet past, even though the topic forms an important part of who she is. 'That is why we like to meet among Estonians, because we understand each other and we know the cultural background.' Among Estonians she does not have to defend or explain herself and they regard the Soviet repressions more or less similarly.

Liisa is one of the few who has had a different experience. The responses she sees among her Dutch interlocutors 'are mostly one of surprise. Did that happen such a short time ago? In your family? It suddenly seems near to them.' The story of Soviet repression is, like for the other interviewees, very important to Liisa because of her family history, but in contrast to the others, Liisa does not experience the same fear of contemporary Russia:

I think that what happened in the Ukraine cannot happen in Estonia, it is a different story. Dutch people ask me all the time whether I am afraid of Russia. No, I am not. It is our big brother, it will always be our neighbour and we need to have a diplomatic relationship with Russia. I also question why Russia would want to have Estonia. We do not have gold, no energy sources, nothing. We only have a good location, also in connection to the sea, but Russia, too, has that.

LIISA, 1977

The difference between the experiences of Liisa and the others illustrates how important it is to feel taken seriously and be equal partners. Because of the 
responses they got while explaining the sufferings during the Soviet period, Siim, Kadri and Anna have the feeling that they are not seen as equal partners by their Dutch compatriots. They have the feeling to be expected to respect their Dutch compatriots, whereas they cannot expect the same from them. This places them in an inferior position, which is especially hurtful in times of insecurity. Liisa, in contrast, perceives her story to be taken seriously, and talking to her Dutch compatriots as an equal.

\section{Double Victims and Agents of Change}

The inequality that Siim, Kadri and Anna perceive with the Dutch while talking about the Soviet repression, hurts not only because it misrecognizes the sufferings of their loved-ones, but also because their Soviet past excludes them from the European family. Italian anthropologist Cappelletto has referred to this phenomenon as 'double victimhood': as the post-generation they have not only become victims of the mass deportations to Siberia, they become victims for the second time because they are not being heard (in this case by 'old Europe').

The way in which Liisa relates to the story of Soviet repression is not as a 'double victim', but rather as an 'agent of change'. The latter term is coined by Iranian Dutch anthropologist Halleh Ghorashi who studied Iranian refugees who arrived in the Netherlands in the 1980 s and post-1990s. ${ }^{36}$ As an agent of change, Liisa realizes she has a voice that counts. She believes that the experience of Soviet repression should not only be seen as a burden that needs to be carried around, but also as an asset in comparison to Dutch people. She explains to me that the pain of being deported - 'a pain of a people (rahvavalu)' - also allows Estonians to put their lives into perspective to an extent that Dutch people cannot. According to Liisa, Dutch people often express: "I don't like that", "I don't want that". They are very ego-centric.' Also Marju, born in 1979 and married to a Dutch man, is able to derive positive lessons from her difficult national past:

I have noticed that my experiences and the way in which I grew up are completely different from the people here. I relate differently to food, for example. I eat even the very last piece, I don't throw anything away. Or when bread is a little bit old, I don't throw it in the bin. You have to eat

36 Halleh Ghorashi, Agents of Change or Passive Victims: The Impact of Welfare States (the Case of the Netherlands) on Refugees, Journal of Refugee Studies 18.2 (2005). 
everything. [...] the same with living space. Here people want the biggest houses and apartments, I am used to small rooms, people lived on top of each other. I don't need so much space. People here are more demanding. [...] History as such does not really trouble me here. But the fact that I have lived through it, that I have the experience of not being free, that we were becoming independent, that has been very ... that you can value what you have, that makes a big difference. And because we did not have much during my first years, I now very much value the fact that we have more than we used to have.

MARJU, 1979

Liisa and Marju thus not only share the story of Soviet repression in the Netherlands because they feel this is their responsibility towards their relatives and their compatriots, but also in order to teach their Dutch friends life lessons they are not able to derive from their own history. By doing so, they do not feel the homesickness and lack of power that double victims express. Agents of change actually feel empowered by sharing their memory of Soviet repression. They see and grasp opportunities. They believe they have the right to tell their story and that they have a voice that counts in the Netherlands.

For Liisa, one such act of grasping opportunities was establishing the 'Estonian School in the Netherlands'. Our interview took place during one of its school days: 'When we established the Estonian School in the Netherlands, it was a really emotional moment for me. You do this with all your heart. It is the language of your heart (südame keel) which speaks here. We want to pass on our culture and language to the next generation.' Instead of feeling disappointed that she could not raise her children in an Estonian context, Liisa grasped the opportunity to create this Estonian School far away from her homeland. The foundation of this school was important to her for various reasons. First of all, many Estonian emigrants find it important to raise their children with a 'national consciousness' and with an 'Estonian cultural spirit'. Estonian intellectual Jakob Hurt said already in 1870: 'We can never become great in strength and numbers, but we can become great in spirit and culture!' Since then, history has proven that culture is the strongest power tool Estonians have, manifested, for example, with the 'Singing Revolution'. Liisa and the other founders hope that the children of Estonian migrants will feel closer connected to the Estonian community by learning its language and social and cultural rules. Secondly, the Estonian school also familiarizes the Dutch with the Estonian culture and language.

Several Estonian emigrants acted as agents of change when they organized a public commemoration of the Soviet deportations in Amsterdam on 25 March 
2011, as portrayed on figure 6.1. Instead of commemorating the event in the safe space of their homes or in company of their Estonian friends, they decided to claim a central public spot (the Dam square in Amsterdam) and the right to share their story of Soviet repression in Dutch society. However, the incentive to organize a public meeting did not come from the Estonian migrants. They were invited to participate by the Estonian organization Tulipisar, which approached

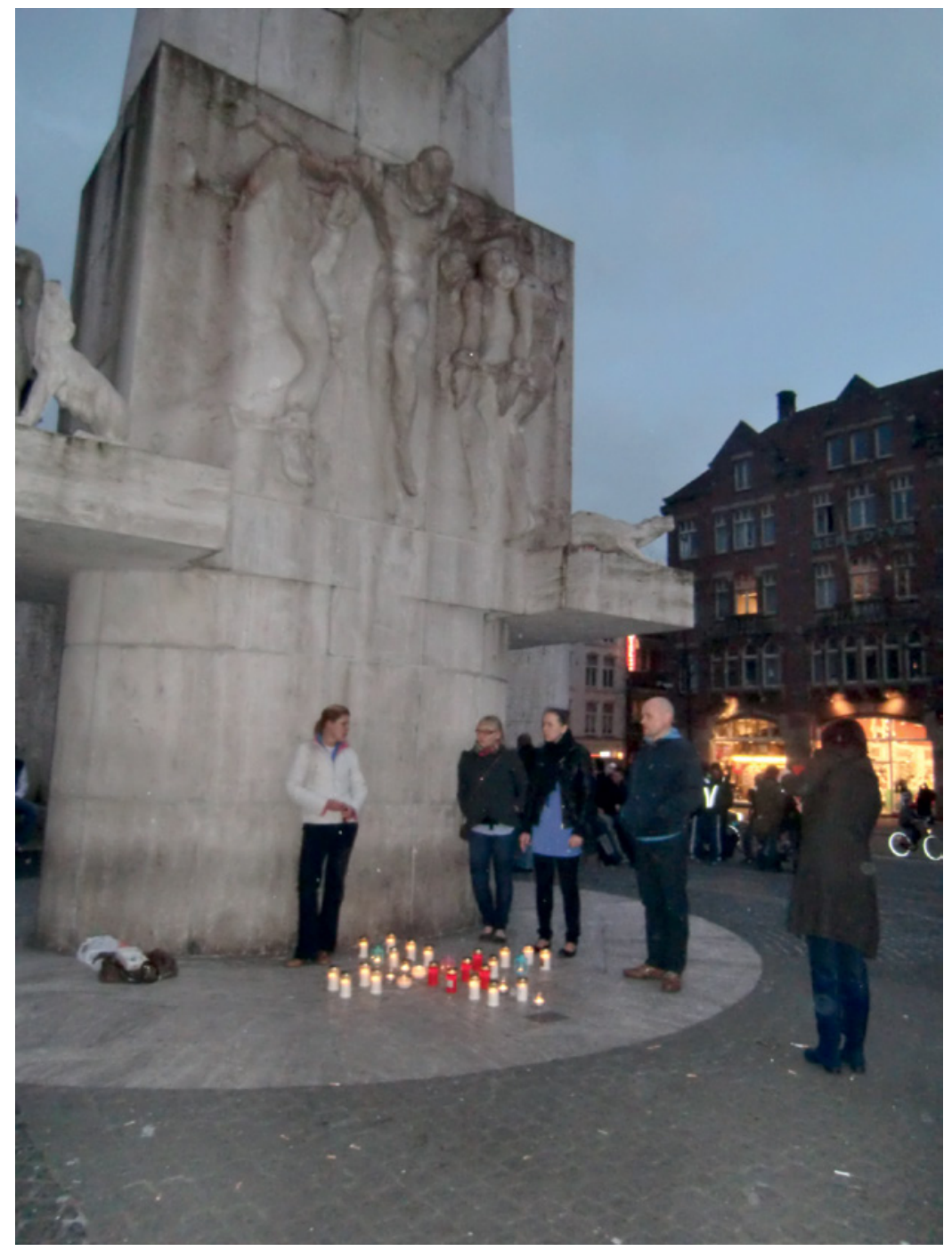

FIGURE 6.1 Remembering the Soviet deportations on the Dam square in central msterdam, 25 March 2011.

SOURCE: TULIPISAR.EE. PERMISSION GRANTED 
the Estonian School to ask if they wanted to light candles to commemorate the 22,00o Estonians who were deported to Siberia on Estonia's Remembrance Day. Estonians all over the world would join them. In Amsterdam around ten Estonians attended, while Dutch people passed by. Backed by the Estonian community all over the world, they dared to act as agents of change and make their voice heard. They lit several candles near the National Monument on Dam Square.

A particular person cannot be characterized as being either a double victim or an active agent. Of course one's personality influences how one positions oneself in a foreign context. But the context is at least as important. When Liisa's Dutch friends would unquestionably judge nationalism politics in Estonia, she might act as a double victim, feeling misunderstood by them. On other occasions, she might act as an agent of change, because she sees opportunities to teach them something new.

A good example of a recent contextual change are the political developments between the Netherlands (and other 'old Europeans') and Russia. Several interviewees mention that the public discourse in the Netherlands - and thus the 'safe space' to share their stories of Soviet repression - has changed drastically. A look into the newspaper articles that have appeared in the Dutch newspaper Volkskrant - aiming at the highly educated and slightly leftist/central population, and one of the three Dutch quality papers - reflects that change.

Right after the Baltic States entered the EU in 2004, the Dutch newspaper did not present a very understanding perspective on the fear that Estonian, Latvian and Lithuanian politicians expressed towards Russia. The fact that the presidents from Estonia, Lithuania and Georgia declined the invitation by Putin in 2005 to commemorate the end of WWII in Moscow, as the end of WWII was for them not a victory but the beginning of the subsequent Soviet occupation, the message was that emotions should not determine politics in a democratic world (Corine de Vries, Volkskrant, 10 May 2005). In the years that followed, the rational and pragmatic approach of the Dutch towards Putin's anti-democratic politics (for example his reaction to the murder of journalist Anna Politkovskaja, one of the most critical opponents of the Russian president) was praised (Bert Lanting, Volkskrant, 19 October 2006). Many EU countries depended on Russia for gas and oil, and closer cooperation was the goal. When Medvedev became Russia's new president in 2008, the EU commissioner Benita Ferrero Waldner spoke about investing in a 'partnership of equals': 'That is of great importance to our companies' (Volkskrant, 27 June 2008).

Understandably, sharing stories of Soviet repression in the Netherlands at this time dit not feel 'safe'. Especially when the five-day summer war between Georgia and Russia broke out, there was an increased wish on the part of the Estonian migrants to be understood, as they wanted to warn their Dutch 
interlocutors of the danger of Russia. They as 'experience experts' had knowledge that the Dutch did not have. However, the attempts by Polish, Lithuanian, Latvian and Estonian presidents to call upon the EU and NATO to decrease the intensity of cooperation with Moscow and to warn of the dangers of Russia, were interpreted as unrealistic fears that should not be taken too seriously (e.g. 'Polen weet wat het betekent', Volkskrant, 12 August 2008; Wim Bossema, Volkskrant, 19 January 2009). Eventually the EU chose not to enforce peace and put sanctions on Russia, but to send observers only (Theo Koelé, Volkskrant, $14 \mathrm{Au}-$ gust 2008). Afraid that their stories of Soviet repression would be interpreted in a similar way as those of the presidents, my informants found it very hard to share their stories and opinions at that time. At the same time, it was also painful to say nothing at all, with respect to their relatives who suffered.

Only three and a half years later, when the political situation in the Ukraine started to deteriorate, the fear felt by the Baltic States and Poland began to be represented as a fear that should be taken seriously. Putin had reacted quite aggressively and undemocratically to the pro-European steps that the Ukraine was taking. Especially the referendum which Putin initiated about the independence of the Crimea was presented as a farce, and the Russian soldiers sent to the Crimea as an illegal annexation that should be condemned (Hans Glaubitz, Volkskrant, 2 September 2014). The EU denied visas to Europe for certain Russian citizens and the European Commission decided to cancel the next EU-Russia summit. On 20 March 2014, the EU council concluded: 'The European Council firmly believes that there is no place for the use of force and coercion to change borders in Europe in the 21st century. The Russian actions are in clear breach of the Helsinki process, which in the past 40 years has contributed to overcoming divisions in Europe and building a peaceful and united continent.'

The EU followed the US and NATO in its condemnation of Russia's aggressive behaviour. Obama explicitly promized and sent the Eastern European countries military support and showed indefinite support for Ukraine's independence (Jan Hunin, Volkskrant, 5 June 2014). In this changing discourse, it was suddenly deemed a possibility that Putin would distort peace in Europe and send Russian jet fighters into European airspace (Stieven Ramdharie, Volkskrant, 30 October 2014). Moreover, what has changed for the Dutch since July 2014 is that emotions are allowed to play a role in the political relationship between Russia and the Netherlands, when the $\mathrm{MH}_{1}$ flight from Amsterdam to Kuala Lumpur was shut down by pro-Russian separatists on Ukrainian territory. According to Dutch minister Bert Koenders, a 'new equilibrium' should be found with Russia, but that 'business as usual is for the Netherlands no longer an option' (Theo Koelé, Volkskrant, 14 May 2015). 
In the present discourse, my Estonian interviewees have the feeling that there is more 'space' for their story of Soviet repression. It resonates better. Also, they have seen that Baltic and Polish politicians are taken more seriously by the old Europeans nowadays. The new members are acknowledged as having knowledge and experience that the Western Europeans lack. In this period, Estonian president Ilves, whose Facebook messages I closely follow, increasingly presented Estonia abroad as an 'experience expert' of Russia, that should be taken seriously: as an agent of change rather than a double victim. By taking that lead, Estonians like Liisa feel more confident sharing their stories as well. Liisa mentions that during the Ukraine referendum in the Netherlands, Dutch people started asking for her stories about Russia. Suddenly those stories resonate more with how their Dutch interlocutors and friends perceive the world. At that moment in time, Estonian emigrants felt that they could openly acknowledge their fear of Russia without the inherent need to defend that fear. It has become an increasingly common fear, instead of one of the new Europeans only.

\section{Conclusion}

In a previous extensive ethnographic study, I argued that the history of Soviet repressions is 'living' in Estonia. 'Living' here refers to the fact that Estonians from various generations are easily emotionally touched when it comes to stories of the repressive Soviet past. The memory of Soviet repression was written in the early 1990s as a 'people's story', in a time when every Estonian citizen was made and felt responsible to contribute to their small, young and newly established nation-state. Not incorporating the story of Soviet repression as part of one's identity as an Estonian is even nowadays often regarded as being a national betrayer.

By following Estonians who moved to the Netherlands (after 2000), I discovered that the Soviet repressions stay with those who have left their homeland. It can even be argued that it becomes more important, as the story is constantly being challenged by their Dutch interlocutors, who have no emotional connection to the Soviet repressions at all. The ethnographic approach taken in this chapter, combined with a focus on people who live outside of their homeland, has revealed that the 'agency' of people should not be overlooked when studying memory reception. After all, as I have found out, the Soviet repressions do not only make Estonians act upon their troubling past as 'double victims' but also as 'agents of change'.

Both within my (previous) fieldwork in Estonia and in the Netherlands, I have mostly encountered double victims. Double victims still suffer from the 
Soviet repression, because of the wounds that have not been healed and have been passed on to the next generation, and because the empathetic listener that is so essential to the healing process is not being met among the Dutch (or old Europeans in general). Many of the Estonians I spoke to - regardless of age and social background - experience a form of misunderstanding in Europe. They demand explicit external recognition as they feel 'existentially insecure' as a people; they are afraid that Estonians as a people might disappear and believe that keeping Estonian culture and history alive will prevent that from happening. ${ }^{37}$ Double victims defend the story of Soviet repression when they meet different understandings of recent history, yet at the same time they already expect 'the Other' to be unable to really understand the Estonian perspective.

In contrast, we met a few agents of change among the Estonians who live in the Dutch context. Agents of change do not defend the Soviet story as an inferior story that needs to be protected from being forgotten, but share it with their Dutch friends as a story from which they can learn something. Agents of change do not see themselves as backwards but as experience experts, not post-Soviets but equal Europeans, who can be teachers of the old Europeans, not only pupils.

The fact that I encountered possibly the first few 'agents of change' in 2015, might be related to changing public discourses, as I have pointed out in this chapter. The political relationship between the EU and Russia has become increasingly tense as the EU has condemned some of Russia's political moves. Thereby the public discourse has altered to a discourse that now resonates more with Estonian stories on the danger of Russia. Estonian emigrants, as opposed to Estonians living in Estonia, might see that there currently is a space in old Europe to share stories of Soviet repression in a sphere of equality and understanding. Moreover, Estonian emigrants might feel even more morally obliged to use the opportunities they have while living among 'the significant Other'; to share their story and educate the others with their unique knowledge. Former victims, who truly know the value of freedom in comparison to the Dutch to whom freedom is a given, become experts on Russia.

If the Estonian agents of change successfully manage to turn the Soviet sufferings from food for a European memory battlefield into important life lessons for all Europeans, then their ancestors will have suffered a little bit less in vain. Besides that, their compatriots back home might not judge them for leaving their homeland for a better life somewhere else, but praise them for being such good Estonian citizens, far away from home. 


\section{Acknowledgements}

I am grateful first and foremost to the Estonians who agreed to be interviewed for this chapter; thank you for your time and trust in my work. I also wish to thank the participants of the cosT conference 'Transcultural memory and reception in Europe' for their contribution to an earlier draft of this chapter, especially to my referent Steffi Hobuss for her extensive comments, and the cosT network for its financial contribution.

\section{Bibliography}

Adler, Nanci. “The Gulag Survivor: Beyond the Soviet System." In On Living Through Soviet Russia, edited by Daniel Bertaux, Paul Thompson and Anna Rotkirch, 212-232. London: Routledge, 2004.

Anepaio, Terje. "Reception of the topic repressions in the Estonian society." Pro Ethnologia 14.9 (2002): 47-66.

Berg, Eiki. "Local resistance, national identity and global swings in Post-Soviet Estonia." Europe-Asia Studies 54-1 (2002): 109-122.

Berliner, David. "The abuses of memory: reflections on the memory boom in anthropology." Anthropological Quarterly 78.1 (2005): 197-211.

Eastmond, Marita. "Stories as Lived Experience: Narratives in Forced Migration Research." Journal of Refugee Studies 20.2 (2007): 248-264.

Elias, Norbert and John L. Scotson. The established and the outsiders. New York: The Humanities Press, 1966.

Gheith, Jehanne M. and Katherine R. Jolluck. Gulag voices: Oral histories of Soviet incarceration and exile. New York: Palgrave Macmillan, 2011.

Ghorashi, Halleh. Agents of Change or Passive Victims: The Impact of Welfare States (the Case of the Netherlands) on Refugees. Journal of Refugee Studies 18.2 (2005): 181-198.

Goodman, Nancy R. and Marilyn B. Meyers, ed. The power of witnessing: Reflections, reverberations, and traces of the Holocaust. London/New York: Routledge, 2012.

Hirsch, Marianne. "The generation of postmemory." Poetics Today 29.1 (2008): 103-128. Hodgkin, Katharine, and Susannah Radstone. "Remembering suffering: trauma and history." In Contested pasts: the politics of memory, edited by Katharine Hodgkin and Susannah Radstone, 97-103. London: Routledge, 2003.

Jõesalu, Kirsti. "The role of the Soviet past in post-Soviet memory politics through examples of speeches from Estonian presidents." Europe-Asia Studies 64.6 (2012): 1007-1032.

Kansteiner, Wulf. "Finding meaning in memory: a methodological critique of collective memory studies." History and Theory 41.2 (2002): 179-197. 
Kõresaar, Ene. "Memory and history in Estonian post-Soviet life stories." PhD diss., Tartu University, 2004.

Lambek, Michael. "Foreword." In Memory and world war II: an ethnographic approach, edited by Francesca Cappelletto, xi-xvii. Oxford: University of Chicago Press, 2005.

Lambek, Michael and Paul Antze. "Introduction: Forecasting memory." In Tense past: Cultural essays in trauma and memory, edited by Michael Lambek and Paul Antze, xi-xxviii. New York: Routledge, 1996.

Malkki, Liisa H. Purity and exile: violence, memory, and national cosmology among hutu refugees in Tanzania. Chicago: The University of Chicago Press, 1995.

Melchior, Inge. "Guardians of Living History: The Persistence of the Past in post-Soviet Estonia." Phd diss., vU University Amsterdam, 2015.

Melchior, Inge. "Forming a common European memory of WWII from a peripheral perspective: Anthropological insight into the struggle for recognition of Estonians, WWII memories in Europe." In Disputed memory: emotions and memory politics in Central, Eastern and South-Eastern Europe, edited by Tea Sindbæk Andersen and Barbara Törnquist-Plewa, 203-226. Berlin: de Gruyter, 2016.

Mole, Richard M.C. The Baltic States from the Soviet Union to the European Union: Identity, discourse and power in the post-communist transition of Estonia, Latvia and Lithuania. London: Routledge, 2012.

Olick, Jeffrey K., and Joyce Robbins. “Social memory studies: From 'collective memory' to the historical sociology of mnemonic practices." Annual Reviews of Sociology 24 (1998): 105-140.

Pettai, Vello A. "Framing the past as future: the power of legal restorationism in Estonia." PhD diss., Columbia University, 2004.

Rahi-Tamm, Aigi. "Human losses." In The white book: losses inflicted on the Estonian nation by occupation regimes 1940-1991, edited by Vello Salo, Ülo Ennuste, Erast Parmasto, Enn Tarvel, and Peep Varju, 25-46. Tallinn: Estonian Encyclopaedia Publishers, 2005.

Snyder, Timothy. Bloodlands: Europe Between Hitler and Stalin. Philadelphia: Basic Books, 2010.

Sztompka, Piotr. From East Europeans to Europeans: Shifting Identities and Boundaries in the New Europe. Wassenaar: NIAs/Netherlands Institute for Advanced Study in the Humanities and Social Sciences, 2004. 